\title{
Barnacle settlement versus recruitment as indicators of larval delivery. II. Time-series analysis and hypothesized delivery mechanisms
}

\author{
Alan L. Shanks* \\ University of Oregon, Oregon Institute of Marine Biology, PO Box 5389, Charleston, Oregon 97420, USA
}

\begin{abstract}
Larval delivery to benthic habitats can strongly influence populations and community structure. Censusing of individuals has been used to infer mechanisms of delivery with measurements made daily of settlement and weekly to monthly of recruitment. Conclusions from these studies are quite different: daily settlement studies find that delivery varies with the spring-to-neap tidal cycle, suggesting shoreward transport by the internal tides, while weekly to monthly recruitment studies find variations related to upwelling and downwelling with delivery due to upwelling relaxation. To resolve this dichotomy, the 2 types of observations were replicated simultaneously. 'Safety Walk' settlement plates were placed in the intertidal zone at Bastendorff Beach, Oregon. Plates were divided into quarters, which were censused daily, weekly, biweekly, and every 4 wk. Settlement was highly pulsed; pulses occurred between the neap and spring tide, with $\sim 74 \%$ of the settlement variability attributable to variation in daily tidal range. Much smaller secondary pulses occurred at the onset of upwelling. The recruitment time series did not correlate with any physical variable, probably due to high cyprid mortality, density-dependent settlement, averaging of physical variables over the sample intervals, and aliasing. Replicating settlement and recruitment studies at the same place and over the same time frame demonstrated that time series of daily settlement provide detailed insight into the possible mechanism of delivery of cyprids to the shore, while recruitment time series did not.
\end{abstract}

KEY WORDS: Cyprid · Settlement · Recruitment · Upwelling $\cdot$ Downwelling $\cdot$ Upwelling relaxation · Internal tides · Balanus glandula

\section{INTRODUCTION}

The amount of larvae delivered to the shore influences populations and the structure and function of communities (Hyder et al. 1998). This is often described as supply-side ecology, and one of the current paradigms in marine ecology is that larval supply is largely determined by hydrographic processes controlling the delivery of larvae to the shore. Studies of daily settlement to open coastal or estuarine settlement sites found that the delivery of larvae to the shore is pulsed, and pulses last several days. In a number of locations, pulses tended to occur either between the neap and spring tide or after the spring tide (Shanks 1983, 1986, 1998, 2006, Pineda 1991, 1994, Olmi 1995, Johnson \& Shanks 2002, Miller \& Shanks 2004, Ladah et al. 2005,
Queiroga et al. 2006, Roegner et al. 2007). These observations suggest that some variation in ocean currents associated with the spring-to-neap tidal cycle, perhaps the internal tides, was responsible for larval delivery. In the Irish Sea, Hawkins \& Hartnoll (1982) observed pulses in barnacle settlement during periods of onshore winds, suggesting transport of larvae by wind-driven onshore surface currents, while Bennell (1981) observed the reverse, i.e. peaks in settlement during offshore winds, suggesting that perhaps local upwelling transported cyprids shoreward.

In contrast, studies of recruitment (defined here as surviving juveniles at the time of a census) at weekly to monthly census intervals arrive at a very different conclusion (e.g. Menge et al. 1999, Connolly et al. 2001, Lagos et al. 2005, Navarrete et al. 2005, Blanchette 
\& Broitman 2006). These researchers conclude that recruitment varied with settlement rate, and settlement varied with upwelling- and downwellingfavorable winds; upwelling carried larvae away from shore, leading to low larval delivery, while downwelling transported them shoreward, leading to high delivery (Alexander \& Roughgarden 1996). These studies addressed questions of large-scale spatial differences in recruitment, but the results were interpreted in a temporal context and used to infer a mechanism of larval delivery.

A consistent difference between these 2 sets of studies is the sample interval: daily versus weekly to monthly censuses. Three explanations may account for the very different conclusions drawn from these studies: (1) post-settlement mortality, (2) densitydependent effects on settlement, and (3) statistical problems generated by the sample design may compromise the capacity of recruitment measurements to define delivery events.

To examine (3), I simultaneously measured daily settlement (newly settled cyprids) and recruitment (surviving juveniles) of intertidal barnacles over weekly and longer intervals using the same sample techniques employed in previous studies. Observations were designed to be 'true replication' (i.e. observations of the same organism in the same habitat using the same sample techniques; Kelly 2006). Observations of barnacle settlement (daily census) and recruitment (weekly, biweekly, and 4 wk censuses) to Safety Walk ${ }^{\circledR}$ settlement plates were made in southern Oregon over $75 \mathrm{~d}$ during the summer of 2007. I hypothesized that (1) daily settlement would provide a detailed description of larval delivery, (2) delivery would correlate with the spring-to-neap tidal cycle, and (3) the recruitment time series would not correlate with any physical mechanisms that might transport cyprids to shore.

\section{MATERIALS AND METHODS}

Observations of barnacle settlement were made from 21 May to 4 August 2007 at a sandstone outcrop located at the southern end of Bastendorff Beach, Oregon $\left(43^{\circ} 20^{\prime} 31.40^{\prime \prime} \mathrm{N}, 124^{\circ} 21^{\prime} 27.91^{\prime \prime} \mathrm{W}\right)$. Details of the study site and setup are provided in Shanks (2009, in this volume). Briefly, 3 replicate Safety Walk settlement plates each were fixed within the densely populated barnacle zone (primarily Balanus glandula) to the east-, west- and north-facing sides of the rock. Each plate was divided into $5 \times 5 \mathrm{~cm}$ quarters. One of these $25 \mathrm{~cm}^{2}$ subsections of each plate was counted daily, weekly, biweekly, and every 4 wk. Censuses were made in the field using a 16-fold magnification hand lens, and plates were inspected daily when the tide was $\leq+1 \mathrm{~m}$. Cyprids and juveniles were enumerated separately. Generally, the entire $25 \mathrm{~cm}^{2}$ section was counted, but when settlement was high (100s to $1000 \mathrm{~s}$ per subsection), only a random quarter of each section was counted. Plates remained attached to the rock during censusing and scrubbing.

Time series of wind speed and direction were obtained from the NOAA Cape Arago weather station located $1.5 \mathrm{~km}$ south of the study site. Using these data and standard equations (Pedlosky 1987), hourly alongshore and cross-shore wind stresses were calculated and averaged to obtain daily wind stresses. Because a constant drag coefficient was used, values should be considered pseudo-wind stresses. The primary purpose of calculating wind stress was to define periods of upwelling- and downwelling-favorable winds. The drag coefficient generally increases with wind speed due to increased sea-surface roughness, but this would have no effect on one's ability to define upwelling- and downwelling-favorable periods. Sea surface temperature (SST) data were obtained from the Coast Guard tide station at Charleston, Oregon (5 km from the study site). The hourly temperature data were used to calculate the average daily temperature. Tide ranges were obtained from NOAA tide tables. Maximum daily tidal range was the maximum range between a high and adjacent low tide for the $24 \mathrm{~h}$ interval between censuses.

Relationships between physical variables and daily cyprid settlement were analyzed with standard time-series techniques (Emery \& Thomson 1997). Daily cyprid settlement data required several transformation steps before analysis. Cyprid settlement was pulsed, with pulses increasing settlement by 1 to 2 orders of magnitude over several days. To normalize these data, they were log-transformed. In addition, there was a longerperiod variation in settlement, probably related to the seasonal timing of spawning, which caused the time series of daily settlement to be autocorrelated at numerous lags, i.e. the data were non-stationary. This longerperiod cycle was removed by first smoothing the logtransformed data with a $17 \mathrm{~d}$ moving average, then calculating a regression between the moving average and the log-transformed data, and lastly, taking the residuals from the regression (StatSoft 1994). The moving average was the shortest necessary to remove the multiple significant autocorrelations, i.e. to make the data stationary. The SST time series was also nonstationary, but only required removal of a linear trend before analysis. Following transformation, the time series were analyzed using autocorrelation, Fourier analysis, and crosscorrelation and cross-Fourier analyses between settlement and physical variables time series. In the cross-correlations, the physical time series was held stationary while settlement was lagged. 


\section{RESULTS}

Fig. 1 shows the daily time series of the physical variables (maximum daily tidal range, alongshore and cross-shore wind stress, average daily seawater temperature, and daily change in temperature) with the average daily cyprid settlement at the sample sites. Daily settlement on the east, north, and west-facing plates was significantly correlated $(\mathrm{r}>0.88, \mathrm{n}=75, \mathrm{p}<$ 0.001 for each correlation); the temporal pattern of settlement at the 3 sites was very similar (Fig. 2). During sampling, there were 5 spring and neap tidal series
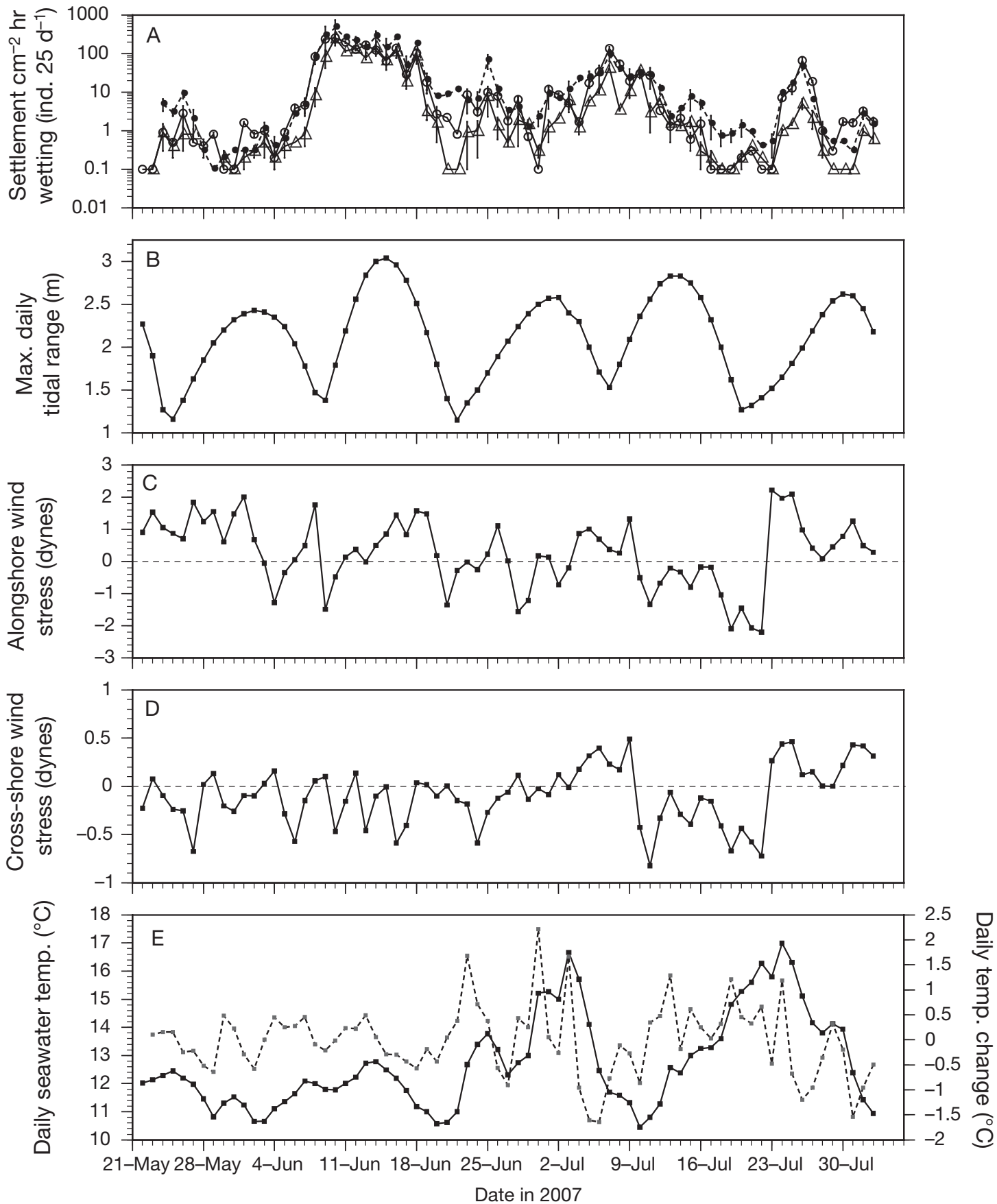

Fig. 1. (A) Daily cyprid settlement, scaled to the hours of submersion, on east- (o), north- $(\bullet)$, and west-facing $(\Delta)$ plates (mean \pm $\mathrm{SE}$ ). (B) Maximum daily tidal range. (C) Alongshore wind stress; positive values are upwelling-favorable. (D) Cross-shore wind stress; negative values are shoreward. (E) (-) Daily sea surface temperature (average of hourly measurements) and (---) daily temperature change $\left(T_{\mathrm{n}}-T_{\mathrm{n}+1}\right)$. Data sources for (B-E) detailed in 'Materials and methods' 

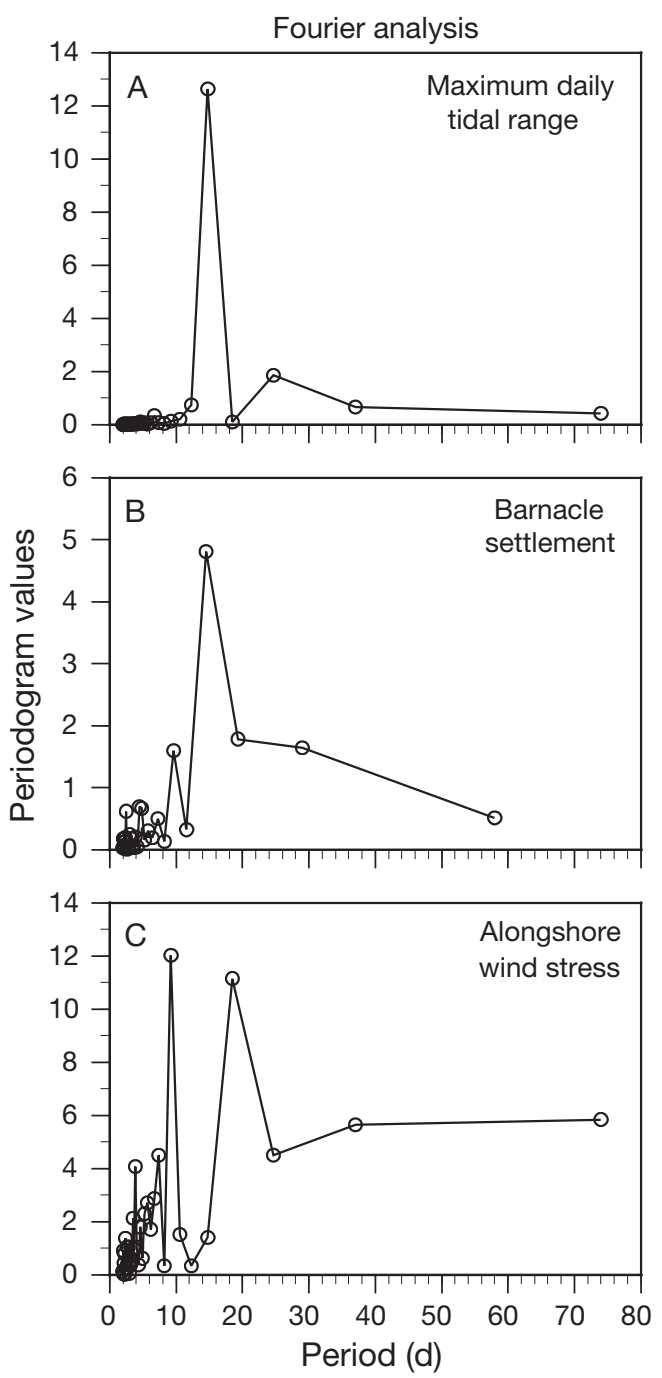

and 5 upwelling (positive wind stress) and downwelling (negative wind stress) events (Fig. 2). Upwelling-favorable winds tended to produce onshore wind stress while downwelling winds did the reverse. Cross-shore wind stress was much weaker than alongshore stress.

Between 22 May and 24 June, SST varied between 10.5 and $12.5^{\circ} \mathrm{C}$ (Fig. 1), and after 24 June between $10.5^{\circ} \mathrm{C}$ and almost $17^{\circ} \mathrm{C}$. Rising SSTs were associated with downwelling-favorable winds (negative wind stress, Fig. 1) while falling SSTs occurred during upwelling winds (positive wind stress, Fig. 1). This can be seen in the cross-correlations (Table 1); there are significant negative cross-correlations between alongshore wind stress and average temperature and temperature change, respectively. Cross-shore wind stress was also significantly negatively cross-correlated with SST and SST change (Table 1); lower and falling SSTs were associated with offshore wind stress (posi-

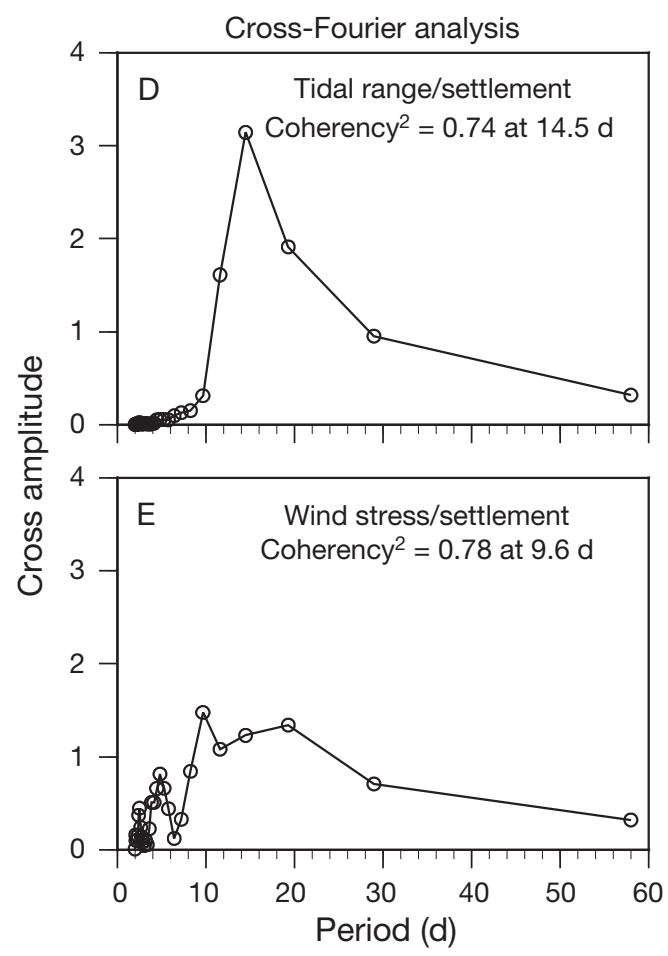

Fig. 2. Fourier analysis of (A) the maximum daily tidal range, (B) transformed cyprid settlement, and (C) alongshore wind stress. Cross-Fourier analysis of (D) maximum daily tidal range and (E) alongshore wind stress with transformed cyprid settlement

tive values, Fig. 1). The relationship between winds and SST is particularly clear from the second half of the observations, during which there were 2 warm events when SST reached $16^{\circ} \mathrm{C}$ and then fell to close to $10^{\circ} \mathrm{C}$ (Fig. 1). In each case, the warming period was associated with an extended period of downwellingfavorable wind stress or little wind stress, while the cooler periods were associated with upwelling wind stress.

SSTs were also significantly cross-correlated with maximum daily tidal range (Table 1 ), with negative correlations at lags of -4 to $-2 \mathrm{~d}$, and tended to be lower 2 to $4 \mathrm{~d}$ after the spring tide. Daily temperature change and maximum daily tidal range were not significantly cross-correlated.

The transformed settlement time series were significantly cross-correlated with the maximum daily tidal range (Table 2). Settlement peaks tended to occur 3 to $4 \mathrm{~d}$ after neap tides (negative correlations with lags of 
Table 1. Cross-correlations between alongshore wind stress, cross-shore wind stress, and maximum daily tidal range with average daily sea surface temperature (SST) and temperature change. The average daily SST time series was detrended prior to running cross-correlations. ns: not significant

\begin{tabular}{|c|c|c|c|c|}
\hline \multirow[t]{2}{*}{$\begin{array}{l}\text { Physical } \\
\text { variable }\end{array}$} & \multicolumn{2}{|c|}{$\begin{array}{c}\text { Avg. daily } \\
\text { seawater temp. }\end{array}$} & \multicolumn{2}{|c|}{$\begin{array}{l}\text { Temp. change } \\
\quad\left(T_{\mathrm{n}}-T_{\mathrm{n}+1}\right)\end{array}$} \\
\hline & $\operatorname{Lag}(\mathrm{d})$ & $\mathrm{r}$ & $\operatorname{Lag}(\mathrm{d})$ & $\mathrm{r}$ \\
\hline $\begin{array}{l}\text { Alongshore } \\
\text { (north/south) } \\
\text { wind stress }\end{array}$ & $\begin{array}{l}-4 \\
-3 \\
-2\end{array}$ & $\begin{array}{l}-0.478 \\
-0.496 \\
-0.417\end{array}$ & $\begin{array}{r}-2 \\
-1 \\
0\end{array}$ & $\begin{array}{l}-0.462 \\
-0.491 \\
-0.393\end{array}$ \\
\hline $\begin{array}{r}\text { Cross-shore } \\
\text { (east/west) } \\
\text { wind stress }\end{array}$ & $\begin{array}{l}-4 \\
-3 \\
-2\end{array}$ & $\begin{array}{l}-0.310 \\
-0.324 \\
-0.291\end{array}$ & $\begin{array}{r}-1 \\
0\end{array}$ & $\begin{array}{l}-0.399 \\
-0.330\end{array}$ \\
\hline $\begin{array}{l}\text { Maximum daily } \\
\text { tidal range }\end{array}$ & $\begin{array}{l}-4 \\
-3 \\
-2\end{array}$ & $\begin{array}{l}-0.249 \\
-0.259 \\
-0.244\end{array}$ & & ns \\
\hline
\end{tabular}

-3 to $-4 d$ ). Fourier analysis found that variation in the spring-to-neap tidal cycle and settlement varied at similar periods (14.8 d tides and $14.5 \mathrm{~d}$ settlement, Fig. 2). Cross-Fourier analyses between the maximum daily tidal range and transformed settlement data found peaks in the cross-amplitude at $14.5 \mathrm{~d}$, and at this period, the squared coherency suggests that $>70 \%$ of the variability in settlement was due to variation in the maximum daily tidal range (Fig. 3). Cyprid settlement varied with the spring-to-neap tidal cycle, with peak settlement occurring between neap and spring tides.

In the Fourier analysis of alongshore wind stress, there were peaks in the periodogram at periods of 18.5 and $9.3 \mathrm{~d}$ (Fig. 2). Near the latter period (9.7 d), a small secondary peak was seen in the periodogram of the settlement data (Fig. 2). This secondary peak was only about a third the size of the peak at $14.8 \mathrm{~d}$, suggesting that, while this peak in the periodogram is significant, much less of the variability in the settlement time series is caused by this period. In the cross-Fourier analyses between alongshore wind stress and settlement a small but significant peak occurred in the cross amplitude at $9.6 \mathrm{~d}$, and at this period, the squared coherency suggests that $77 \%$ of the variability in settlement was due to variation in alongshore wind stress. The results suggest that, while much of the variation in settle- ment was related to the spring-to-neap tidal cycle, settlement also varied, although more weakly, with alongshore wind stress.

Alongshore and cross-shore wind stress were significantly positively cross-correlated with cyprid settlement on the east- and north-facing but not the westfacing plates (Table 2). Average SST was positively and the change in SST was negatively cross-correlated with cyprid settlement with lags of 0 to $-4 \mathrm{~d}$ on all plates (Table 2). Peaks in settlement tended to occur on or a couple of days after upwelling-favorable winds and offshore winds occurred and when temperatures were low or falling; secondary settlement peaks occurred during upwelling.

In Fig. 3, the weekly, biweekly, and 4 wk recruitment to the plates is plotted with the average maximum daily tidal range, alongshore wind stress, and seawater temperature for each sample interval. Correlations and cross-correlations were run between weekly and biweekly recruitment to the plates and averaged physical variables. The $4 \mathrm{wk}$ time series was too short for correlation analysis. None of the correlations between weekly or biweekly recruitment data and the physical data were significant.
Table 2. Cross-correlations between physical variables and daily crprid settlement on the east-, north-, and west-facing settlement plates. Before analysis, the settlement data were log-transformed, a $17 \mathrm{~d}$ moving average was calculated, and then the log-transformed and moving average time series were residualized (see 'Materials and methods'). A linear trend was removed from the seawater temperature time series before analyses. Reported are the days lag and r-values for cross-correlations significant at $\mathrm{p} \leq 0.05$. ns: not significant

\begin{tabular}{|c|c|c|c|c|c|c|}
\hline \multirow{2}{*}{ Physical variable } & \multicolumn{2}{|c|}{$\longrightarrow$ East $\longrightarrow$} & \multicolumn{2}{|c|}{ — North } & \multicolumn{2}{|c|}{$\ldots$ West } \\
\hline & $\operatorname{Lag}(d)$ & $\mathrm{r}$ & $\operatorname{Lag}(d)$ & $\mathrm{r}$ & $\operatorname{Lag}(d)$ & $\mathrm{r}$ \\
\hline $\begin{array}{l}\text { Max. daily } \\
\text { tidal range }\end{array}$ & $\begin{array}{l}-5 \\
-4 \\
-3 \\
-2 \\
-1 \\
+2 \\
+3 \\
+4 \\
+5\end{array}$ & $\begin{array}{r}-0.357 \\
-0.435 \\
-0.432 \\
-0.378 \\
-0.264 \\
0.343 \\
0.471 \\
0.507 \\
0.481\end{array}$ & $\begin{array}{l}-5 \\
-4 \\
-3 \\
-2 \\
+2 \\
+3 \\
+4 \\
+5\end{array}$ & $\begin{array}{r}-0.314 \\
-0.391 \\
-0.397 \\
-0.342 \\
0.309 \\
0.418 \\
0.457 \\
0.442\end{array}$ & $\begin{array}{l}-5 \\
-4 \\
-3 \\
-2 \\
-1 \\
+1 \\
+2 \\
+3 \\
+4 \\
+5\end{array}$ & $\begin{array}{r}-0.318 \\
-0.397 \\
-0.433 \\
-0.404 \\
-0.285 \\
0.345 \\
0.497 \\
0.551 \\
0.498 \\
0.392\end{array}$ \\
\hline $\begin{array}{l}\text { Alongshore } \\
\text { wind stress }\end{array}$ & $\begin{array}{r}-2 \\
-1 \\
0\end{array}$ & $\begin{array}{l}0.330 \\
0.447 \\
0.412\end{array}$ & $\begin{array}{r}-1 \\
0\end{array}$ & $\begin{array}{l}0.341 \\
0.312\end{array}$ & & ns \\
\hline $\begin{array}{l}\text { Cross-shore } \\
\text { wind stress }\end{array}$ & $\begin{array}{l}-2 \\
-1\end{array}$ & $\begin{array}{l}0.302 \\
0.377\end{array}$ & -1 & 0.300 & & ns \\
\hline $\begin{array}{l}\text { Avg. seawater } \\
\text { temp. }\end{array}$ & $\begin{array}{l}-4 \\
-3 \\
-2\end{array}$ & $\begin{array}{l}0.412 \\
0.437 \\
0.402\end{array}$ & $\begin{array}{l}-4 \\
-3 \\
-2 \\
-1\end{array}$ & $\begin{array}{l}0.355 \\
0.400 \\
0.415 \\
0.311\end{array}$ & $\begin{array}{l}-4 \\
-3 \\
-2\end{array}$ & $\begin{array}{l}0.350 \\
0.397 \\
0.350\end{array}$ \\
\hline $\begin{array}{l}\text { Change in avg. } \\
\text { seawater temp. }\end{array}$ & $\begin{array}{r}-1 \\
0\end{array}$ & $\begin{array}{l}-0.369 \\
-0.433\end{array}$ & 0 & -0.389 & $\begin{array}{r}-1 \\
0\end{array}$ & $\begin{array}{l}-0.275 \\
-0.327\end{array}$ \\
\hline
\end{tabular}



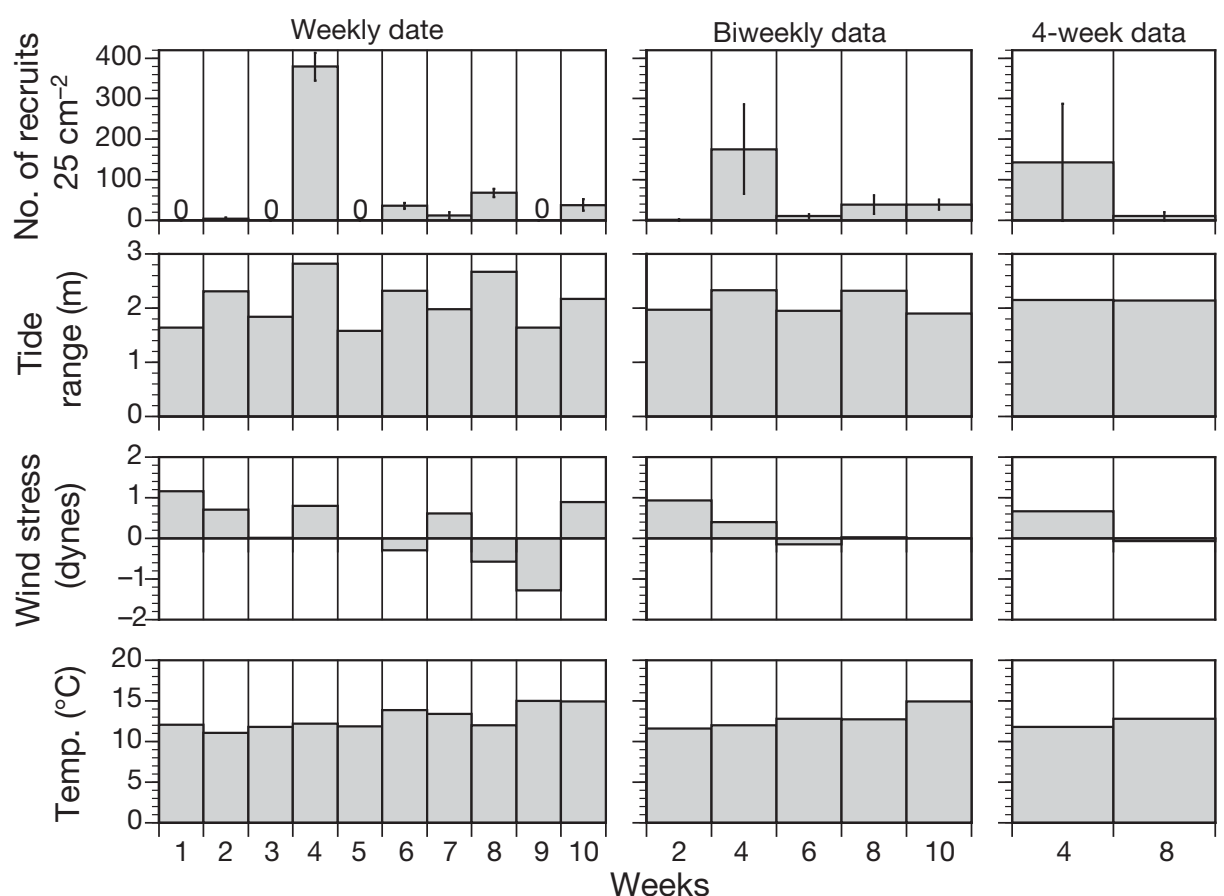

Weeks

Fig. 3. Weekly, biweekly, and $4 \mathrm{wk}$ barnacle recruitment on the east-facing plates plotted with the maximum daily tidal range, alongshore wind stress, and seawater temperature averaged over each recruitment interval. Data are means $\pm \mathrm{SE}$

\section{DISCUSSION}

Researchers have used measurements of daily larval settlement or recruitment at weekly to monthly intervals to investigate the role of coastal hydrography in determining larval supply. The 2 types of studies investigate larval delivery at very different temporal scales and arrive at very different conclusions. The purpose of the present study was to determine why this is so. The differing conclusions may be due to postsettlement mortality and density-dependent effects on settlement (Shanks 2009), or to statistical problems generated by the differing sample intervals.

In time-series analysis, one can only analyze cycles that are $\geq 2$ times the sample interval (Emery \& Thomson 1997). This is known as aliasing and is a severe restriction on statistical analyses of a time series. There is an additional limitation due to aliasing; if there are strong cycles in the portion of the time domain that cannot be resolved, then these cycles can produce false cycles in the time series at periods that can be resolved (Emery \& Thomson 1997). The spring-to-neap tidal cycle has a period of about $14 \mathrm{~d}$, while the direction of coastal winds changes roughly every 4 to $11 \mathrm{~d}$ (Huyer 1983, Send et al. 1987). Because of aliasing, recruitment samples collected at weekly to monthly intervals cannot be used to investigate transport of larvae by either the fortnightly tidal cycle or wind-driven coastal currents. Samples collected at these longer intervals can be used to investigate forcers with cycles longer than 15 to $62 \mathrm{~d}$. Daily samples can be used to investigate cycles with periods $>2 \mathrm{~d}$ and, hence, the effects of the fortnightly tidal cycle and variations in winds can be studied.

There were 2 peaks in the Fourier analysis of settlement: a larger peak at $14.5 \mathrm{~d}$ and a smaller peak at $9.7 \mathrm{~d}$ (Fig. 3). In the cross-Fourier analysis between the maximum daily tidal range and settlement, $74 \%$ of the variability in settlement at the $14.5 \mathrm{~d}$ period was attributable to variation in tidal range (Fig. 3). The crossFourier analysis suggests that the smaller peak at $9.7 \mathrm{~d}$ was due to variation in alongshore winds (Fig. 3). Cross-correlations analysis indicated that peak cyprid settlement occurred between neap and spring tides and at the onset of upwelling events (Table 2). Cyprid settlement was associated with 2 forcers: a dominant forcer, the spring-to-neap tidal cycle, and a weaker one associated with the onset of upwelling.

Shanks (1986) and Pineda (1991) sampled daily cyprid settlement in the Southern California Bight and found settlement to vary with the spring-to-neap tidal cycle; a wind effect was not evident. Farrell et al. (1991) censused cyprids on plates every $2 \mathrm{~d}$ and concluded that peaks in settlement occurred during upwelling relaxation events; however, no statistical analysis was done. The dataset of Farrell et al. (1991) 
was statistically analyzed by Shkedy \& Roughgarden (1997), who investigated the relationship between recruitment and alongshore wind, the Bakun upwelling index, and SST, but neglected to investigate a tidal effect. I digitized Farrell et al.'s (1991, their Fig. 2A) settlement data using Image $J$ software and statistically compared settlement to the predicted maximum daily tidal range and wind stress obtained from NOAA Buoy \#46028 (wind data used in Farrell et al. 1991). Significant peaks in the Fourier analysis of settlement, maximum daily tidal range, and alongshore wind were found at periods of $7.2 \mathrm{~d}(14.4 \mathrm{~d}), 7.5$ and $14 \mathrm{~d}$ (14 and $28 \mathrm{~d}$ ), and 7, 10.9, and $24.5 \mathrm{~d}$ (14, 21.8 , and 29 d), respectively (Fig. 4). In the crossFourier analysis, there were no significant crossamplitudes between alongshore wind stress and settlement, nor were there any significant cross-correlations between wind stress and settlement. Significant cross-amplitudes between tidal range and settle-
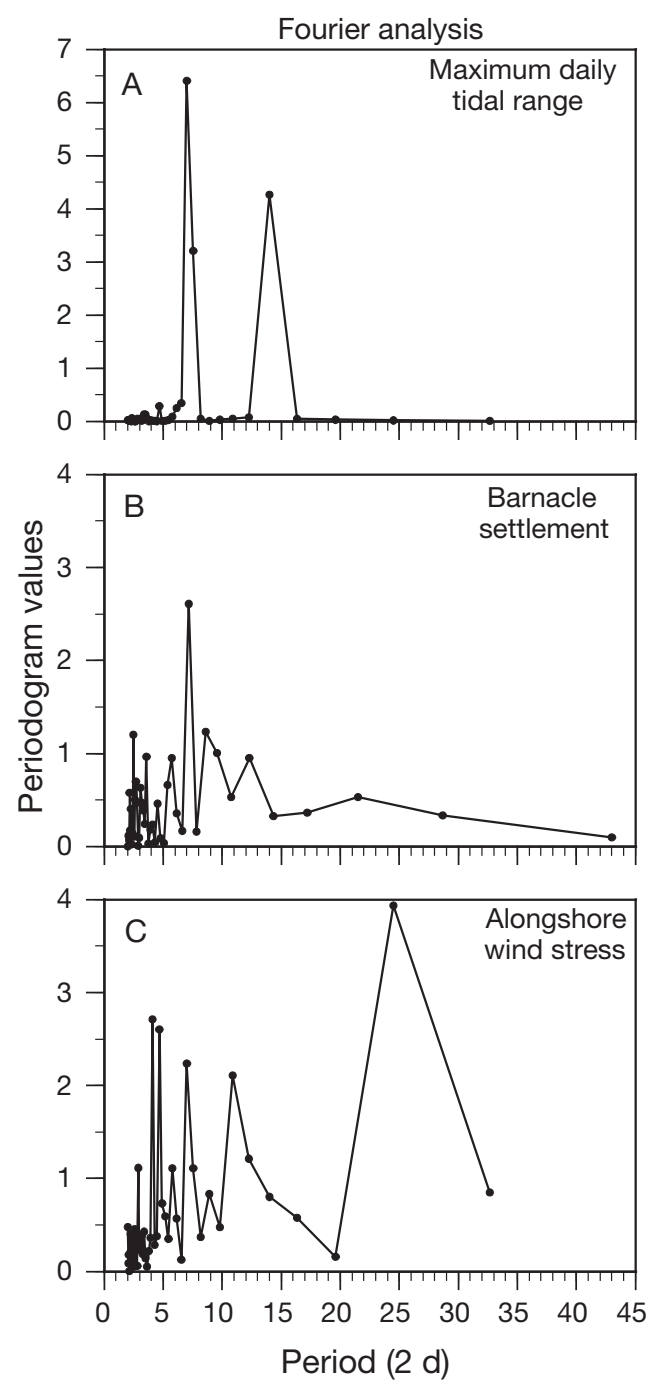

ment were found at a period of $7.2 \mathrm{~d}$ (14.4 d, Fig. 4). The squared coherency suggests that, at this period, 48 to $72 \%$ of the variability in settlement could be attributed to variation in tidal range. The cross-correlation analysis indicated that peak settlement occurred between neap and spring tides. The conclusions from an analysis of Farrell et al.'s (1991) data using standard time-series techniques are nearly identical to those reported in Shanks (1986), Pineda (1991), and the present study. In these 4 studies spanning the west coast from the Southern California Bight to southern Oregon, the dominant forcer of barnacle settlement was the spring-to-neap tidal cycle with either no or a weak variation due to wind stress. The dominant cycles in studies that have measured daily cyprid settlement are at periods of $\sim 14 \mathrm{~d}$ (springto-neap tidal cycle) and, in the present study, more weakly at $\sim 9 \mathrm{~d}$ (alongshore wind stress); hence, due to aliasing, weekly to monthly sample intervals in recruit-

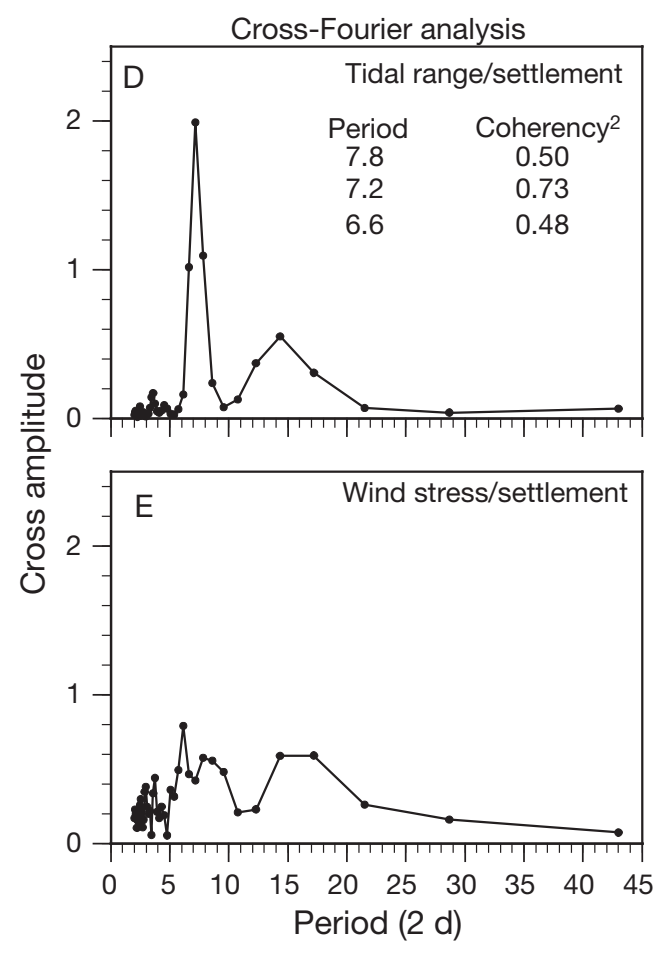

Fig. 4. Reanalysis of cyprid settlement data presented in Farrell et al. (1991); see 'Discussion' in the present study for methods. Fourier analysis of (A) the maximum daily tidal range, (B) transformed cyprid settlement, and (C) alongshore wind stress. Cross-Fourier analysis of (D) maximum daily tidal range and (E) alongshore wind stress with transformed cyprid settlement. Farrell et al. (1991) sampled every other day; period in the analysis is thus $2 \mathrm{~d}$ 
ment studies are too long to resolve the dominant cycles in cyprid settlement.

Despite the obvious problems with the statistical analysis of the recruitment time series, I ran crosscorrelations between the recruitment and physical data time series. I found no significant correlations at any lag; the recruitment data provided no insight into the hydrographic forcers that might transport cyprids to shore and cause variation in settlement.

Like the studies of cyprid recruitment, researchers have followed recruitment of other organisms to artificial substrates and interpreted variation in recruitment as being due to variation in larval delivery. For example, Wing et al. (1995) followed the weekly recruitment of Cancer magister megalopae to brushes, and numerous studies have followed the recruitment at weekly and longer intervals of intertidal mussels to 'Tuffy' artificial substrates (e.g. Menge et al. 1997, 1999, Blanchette \& Broitman 2006). By sampling at weekly or longer intervals, these studies may also suffer from aliasing, which will prevent meaningful interpretation of the data. Indeed, in the case of C. magister megalopae, studies of daily abundance have found that delivery to the shore is highly pulsed and varies with the spring-to-neap tidal cycle (Johnson \& Shanks 2002, Miller \& Shanks 2004, Shanks 2006, Roegner et al. 2007).

Shanks \& Shearman (2009, in this volume) and Morgan et al. (2009) sampled meroplankton during the summer upwelling season off southern Oregon and northern California, respectively. Stratified zooplankton samples were collected along a transect perpendicular to shore with the most nearshore station located $\leq 1 \mathrm{~km}$ offshore. The conclusions from these studies are identical. Nearly all cyprids of intertidal barnacles were caught within $5 \mathrm{~km}$ of shore, they were abundant at the most inshore station, and their cross-shelf distribution did not change with upwelling and downwelling; in both conditions, they were caught close to shore and were rare beyond $5 \mathrm{~km}$. Cyprids avoided the upper 5 to $10 \mathrm{~m}$ of the water column, i.e. they avoided the Ekman layer. At a study site on the Oregon coast, Rilov et al. (2008) found that the larvae of intertidal mussels were persistently present just outside the surf zone throughout the summer upwelling season during upwelling and downwelling conditions. Shanks \& Shearman (in press) found mussel larvae to be similarly distributed. Shanks et al. (2003), in a study of very-nearshore hydrography on the Oregon coast, found cyprids and mussel larvae to be consistently present 10 s to 100 s of meters offshore even during upwelling events. The larvae of intertidal invertebrates are not swept far from shore by upwelling events, but are present just outside the surf zone during upwelling and downwelling.
Due to aliasing, studies that have followed the recruitment of intertidal organisms at weekly or longer intervals cannot investigate the mechanisms of larval delivery if the hydrography transporting larvae shoreward occurs at periods $<14 \mathrm{~d}$, yet many of these studies conclude that variations in recruitment were driven by upwelling and downwelling affecting the delivery of larvae to the shore. Many of these recruitment studies were investigating latitudinal variations in recruitment, which appeared to correlate with latitudinal variations in the strength and persistence of upwelling and downwelling; in other words, they were looking at variations on large spatial scales and interpreting the results as being due to temporal variations in the delivery of larvae to the shore. Besides the problem of aliasing in the sample design, there are several problems with this interpretation of results. First, Safety Walk settlement plates heat up rapidly in the sun, which kills newly settled cyprids (Shanks 2009); the data from studies that have followed barnacle recruitment using Safety Walk plates may be unreliable. Second, one can imagine a variety of variables that may vary latitudinally and affect barnacle recruitment (e.g. wave energy, sunlight, timing of the daytime low tide, distribution of predators, etc.), but variations in recruitment have only been related to upwelling/downwelling. Third, this interpretation is dependent on larvae being swept offshore by upwelling and transported to shore by downwelling, yet recent studies (see previous paragraph) have found that the cross-shelf distributions of many types of meroplankton, including larvae of intertidal barnacles, remain unchanged despite upwelling and downwelling, and the larvae are distributed from just outside the surf zone to about $5 \mathrm{~km}$ offshore. In fact, the settlement data reported here suggest that peaks in settlement tended to occur on a fortnightly cycle and relative to variations in upwelling and downwelling, but peak settlement occured at the onset of upwelling and not during downwelling, suggesting that upwelling caused shoreward transport.

A number of studies have found that larval delivery was highly pulsed and that delivery was correlated significantly with the maximum daily tidal range. Shanks (1983) hypothesized that large tidally generated internal waves, the internal tides, transport larvae shoreward. Zooplankton sampling over internal waves and the shoreward transport of surface drifters by the internal waves demonstrated the hypothesis to be correct (Shanks 1983, 1988, Shanks \& Wright 1987). There are several species for which both zooplankton samples over internal waves and time series of daily larval delivery exist (e.g. Pachygrapsus crassipes megalopae, Shanks 1983; Callinectes sapidus megalopae, Shanks 1988, 1998; Penaeus spp. post-larvae, Shanks 1988, 1998; and cyprids, Shanks 1986, Pineda 1991, Shanks 
\& Wright 1987). In each case, zooplankton sampling indicated that larvae were transported shoreward by internal waves, and the settlement time series had the characteristic pattern of pulsed delivery, with pulses correlated with the maximum daily tidal range. It seems reasonable to hypothesize that, when delivery time series are significantly correlated with the maximum daily tidal range, delivery was forced by the internal tides. From southern California to southern Oregon, daily time series of cyprid settlement are significantly correlated to the maximum daily tidal range, suggesting that, over this entire length of shore, onshore transport of cyprids may be forced by internal tides.

Fourier analysis and cross-correlations indicate that peaks in cyprid settlement also tended to occur at the onset of upwelling. This can be most clearly seen by the significant positive cross-correlations with short lags between wind direction and settlement (higher settlement with north winds) and significant negative correlations with short lags between seawater temperature and settlement (higher settlement during periods of cold water); upwelling was associated with enhanced delivery of cyprids to the shore. Cyprids of intertidal barnacles are present just outside the surf zone and below the surface Ekman layer. At the onset of upwelling, water below the surface Ekman layer may flow shoreward and the relationship between upwelling and settlement suggests that this onshore flow may deliver cyprids to the intertidal zone.

The purpose of the present study was to determine why studies that have measured cyprid settlement daily or barnacle recruitment at weekly or longer intervals have arrived at very different conclusions as to the mechanism(s) causing delivery of cyprids to the shore. By measuring settlement and recruitment using the same standard techniques at the same place and time, the 2 types of studies were exactly replicated, allowing direct comparison of the results and conclusions. From this work, I draw the following conclusions: (1) In the daily-settlement time series, settlement was pulsed with peaks occurring between neap and spring tides and, to a lesser degree, at the onset of upwelling events. These results lead to the hypotheses that delivery of cyprids to the shore was primarily due to the internal tides and, to a lesser extent, due to the onset of upwelling and (2) due to aliasing, the recruitment time series provided no insight into the mechanism(s) causing variation in the delivery of cyprids to the shore.

Acknowledgements. Funding provided by National Science Foundation Small Grant for Exploratory Research OCE 0715425. When I was out of town, the following people counted cyprids: L. Shanks, G. Shanks, S. Schroeder, J. Marin Jarrin, A. Leferriere, E. Cooper, A. Pollard, and K. Bennett. J. Hodder, J. Miller, and C. Roegner commented on drafts of the paper.

\section{LITERATURE CITED}

Alexander SE, Roughgarden J (1996) Larval transport and population dynamics of intertidal barnacles: a coupled benthic/oceanic model. Ecol Monogr 66:259-275

Bennell SJ (1981) Some observations on the littoral barnacle populations of North Wales. Mar Environ Res 5:227-240

Blanchette C, Broitman B (2006) Intertidal community structure and oceanographic patterns around Santa Cruz Island, CA, USA. Mar Biol 149:689-701

Connolly SR, Menge BA, Roughgarden J (2001) A latitudinal gradient in recruitment of intertidal invertebrates in the northeast Pacific Ocean. Ecology 82:1799-1813

Emery WJ, Thomson RE 1997. Data analysis methods in physical oceanography. Elsevier Science, New York, NY

Farrell TM, Bracher D, Roughgarden J (1991) Cross-shelf transport causes recruitment to intertidal populations in central California. Limnol Oceanogr 36:279-288

> Hawkins SJ, Hartnoll RG (1982) Settlement patterns of Semibalanus balanoides (L.) in the Isle of Man (1977-1981). J Exp Mar Biol Ecol 62:271-283

> Huyer A (1983) Coastal upwelling in the California current system. Prog Oceanogr 12:259-284

> Hyder K, Johnson MP, Hawkins SJ, Gurney WSC (1998) Barnacle demography: evidence for an existing model and spatial scales of variation. Mar Ecol Prog Ser 174:89-99

Johnson J, Shanks AL (2002) Time series of the abundance of the post-larvae of the crabs Cancer magister and Cancer spp. on the southern Oregon coast and their cross-shelf transport. Estuaries 25:1138-1142

Kelly CD (2006) Replicating empirical research in behavioral ecology: how and why it should be done but rarely ever is. Q Rev Biol 81:221-236

> Ladah LB, Tapia FJ, Pineda J, Lopez M (2005) Spatially heterogeneous, synchronous settlement of Chthamalus spp. larvae in northern Baja California. Mar Ecol Prog Ser 302: $177-185$

Lagos N, Navarrete S, Veliz F, Masuero A, Castilla J (2005) Meso-scale spatial variation in settlement and recruitment of intertidal barnacles along the coast of central Chile. Mar Ecol Prog Ser 290:165-178

Menge BA, Daley BA, Wheeler PA, Dahlhoff EP, Sanford E, Strub PT (1997) Benthic-pelagic links and rocky intertidal communities: bottom-up effects on top-down control? Proc Natl Acad Sci USA 94:14530-14535

Menge BA, Daley BA, Lubchenco J, Sanford E, Dahlhoff E, Halpin PM, Hudson G, Burnaford JL (1999) Top-down and bottom-up regulation of New Zealand rocky intertidal communities. Ecol Monogr 69:297-330

> Miller JA, Shanks AL (2004) Ocean-estuary coupling in the Oregon upwelling region: the abundance and transport of juvenile fish and larval invertebrates. Mar Ecol Prog Ser 271:267-279

Morgan S, Fisher JL, Mace AJ, Akins LJ, Slaughter AM, Bollens SM (2009) Cross-shelf distributions and recruitment of crab larvae in a region of strong upwelling. Mar Ecol Prog Ser 380:173-185

> Navarrete SA, Wieters E, Broitman B, Castilla J (2005) Scales of benthic-pelagic coupling and the intensity of species interactions: from recruitment limitation to top-down control. Proc Natl Acad Sci USA 102:18046-18051

Olmi EJI (1995) Ingress of blue crab megalopae in the York River, Virginia, 1987-1989. Bull Mar Sci 57:753-780

Pedlosky J 1987. Geophysical fluid dynamics, 2nd edn. Springer-Verlag, New York, NY

Pineda J (1991) Predictable upwelling and the shoreward transport of planktonic larvae by internal tidal bores. Science 253:548-551 
Pineda J (1994) Spatial and temporal patterns in barnacle settlement rate along a southern California rocky shore. Mar Ecol Prog Ser 107:125-138

Queiroga H, Almeida M, Alpuim T, Flores A and others (2006) Tide and wind control of megalopal supply to estuarine crab populations on the Portuguese west coast. Mar Ecol Prog Ser 307:21-36

Rilov G, Dudas S, Menge B, Grantham B, Lubchenco J, Schiel D (2008) The surf zone: a semi-permeable barrier to onshore recruitment of invertebrate larvae? J Exp Mar Biol Ecol 361:59-74

Roegner GC, Armstrong DA, Shanks AL (2007) Wind and tidal influences on larval crab recruitment to an Oregon estuary. Mar Ecol Prog Ser 351:177-188

Send U, Beardsley RC, Winant CD (1987) Relaxation from upwelling in the Coastal Ocean Dynamics Experiment. J Geophys Res 92:1683-1698

Shanks AL (1983) Surface slicks associated with tidally forced internal waves may transport pelagic larvae of benthic invertebrates and fishes shoreward. Mar Ecol Prog Ser 13: 311-315

Shanks AL (1986) Tidal periodicity in the daily settlement of intertidal barnacle larvae and an hypothesized mechanism for the cross-shelf transport of cyprids. Biol Bull (Woods Hole) 170:429-440

Shanks AL (1988) Further support for the hypothesis that internal waves can transport larvae of invertebrates and fish onshore. Fish Bull (Wash DC) 86:703-714

Shanks AL (1998) Abundance of post-larval Callinectes sapidus, Penaeus spp., Uca spp., and Labinia spp. collected at an outer coastal site and their cross-shelf transport. Mar

Editorial responsibility: Otto Kinne, Oldendorf/Luhe, Germany
Ecol Prog Ser 168:57-69

Shanks AL (ed) (2001) An identification guide to the larval marine invertebrates of the Pacific Northwest. Oregon State University Press, Corvallis, OR

Shanks AL (2006) Mechanisms of cross-shelf transport of crab megalopae inferred from a time series of daily abundance. Mar Biol 148:1383-1398

Shanks AL (2009) Barnacle settlement versus recruitment as indicators of larval delivery. I. Effects of post-settlement mortality and recruit density. Mar Ecol Prog Ser 385: 205-216

Shanks AL, Shearman RK (2009) Paradigm lost? Cross-shelf distributions of intertidal invertebrate larvae were unaffected by upwelling or downwelling. Mar Ecol Prog Ser 385:189-204

Shanks AL, Wright WG (1987) Internal-wave-mediated shoreward transport of cyprids, megalopae, and gammarids and correlated longshore differences in the settling rate of intertidal barnacles. J Exp Mar Biol Ecol 114:1-13

> Shanks AL, McCulloch AA, Miller J (2003) Topographically generated fronts, very nearshore oceanography and the distribution of larval invertebrates and holoplankters. J Plankton Res 25:1251-1277

Shkedy Y, Roughgarden J (1997) Barnacle recruitment and population dynamics predicted from coastal upwelling. Oikos 80:487-498

StatSoft 1994. Statistica for the Macintosh. StatSoft, Tulsa, OK > Wing SR, Botsford LW, Largier JL, Morgan LE (1995) Spatial structure of relaxation events and crab settlement in the northern California upwelling system. Mar Ecol Prog Ser 128:199-211

Submitted: July 4, 2008; Accepted: March 9, 2009 Proofs received from author(s): June 9, 2009 